\title{
sciendo
}

Research Article

(c) 2018 Joseph Ching Velasco and Jeremy de Chavez. This is an open access article licensed under the Creative Commons Attribution-NonCommercial-NoDerivs License (http://creativecommons.org/licenses/by-nc-nd/3.0/).

\section{Millennial Work Ethic: A Preliminary Examination of the Work Ethic Profile of Filipino University Students}

\author{
Joseph Ching Velasco
}

Behavioral Sciences Department

De La Salle University, Philippines

\section{Jeremy de Chavez}

Department of English

Faculty of Arts and Humanities

University of Macau, Macau SAR

Doi: 10.2478/mjss-2018-0167

\begin{abstract}
At present, most students in the universities are considered millennials. As explained by Delcampo, Haggerty, Haney, and Knippel (2010), millennials are individuals born from 1981-2000. In general, millennials are perceived to be the "me" generation or "hero" generation. In addition, they are criticized as individuals who are self-centered, unmotivated, disrespectful, and disloyal (Myers \& Sadaghiani, 2010). Given the conflicting and, to some extent, uncritical generalizations about the millennial cohort, this paper explores the work ethic profile of Filipino millennial university students. The respondents of this study are 248 university students from a private university in Metro Manila, Philippines. Through the Multidimensional Work Ethic Profile - Short Form (MWEP-SF), the seven dimension of work ethic were described. Results reveal that Filipino millennial university students scored high on self-reliance. Likewise, they have high mean scores in the dimensions of centrality of work, wasted time, morality/ethics, delay of gratification, and hard work. The dimension of leisure is ranked the lowest. The findings further reveal that there are significant differences in work ethic between male and female respondents. However, in terms of academic specialization, no significant differences were observed. Considering academic achievement, workload, and study hours, these factors interact with the different facets of work ethic.
\end{abstract}

Keywords: millennials, Filipino university student, work ethic, Generation Y, ethics, work

\section{Introduction}

At the present time, most of the university students are classified as millennials. This generational cohort is born from 1981-2000 (Delcampo, Haggerty, Haney, \& Knippel, 2010). This generational cohort is characterized by their dependence on technology as compared to preceding generations such as the Generation X and Baby Boomers. Barnes (2009) illumines that millennials are either described as the "me generation" or the "hero generation." Considering the former, millennials are perceived to be highly self-focused and entitled. Conversely, they are also called the "hero generation" for being well rounded, civic minded, and with great self-esteem.

Given the polarity of how millennials are depicted in the literature, examining their work ethic sheds light on their attitude and behavior with respect to work. Going back to the beginning of work ethic as a concept in the social sciences, Max Weber in his work The Protestant Ethic and the Spirit of Capitalism (1905) examined how religious ideas, specifically Calvinism, paved the way for the 
rise of capitalism. His concept of the Protestant Work Ethic requires a certain type of predisposition toward work - soberness, frugality, sexual restraint, and a constrained way of living life (Chasovschi, 2016). The concept of work ethic in contemporary times does not necessarily deviate from Weber's arguments; rather, it is simply reinterpreted and further secularized. Meriac, Woehr, and Bannister (2010) define work ethic in today's modern context as a belief system that reflects the fundamental value of work.

Numerous instruments and scales have been created through Weber's argument on work. Mirels and Garret (1971) created the Protestant Work Ethic Scale that quantified the aspects of work ethic. The scale was developed with the following dimensions: success, asceticism, antileisure, and hard work. It is considered to be a groundbreaking work in the exploration of work ethic; however, it did not include other essential elements of work ethic such as self-reliance, morality, and delay of gratification. Aside from the Protestant Work Ethic Scale of Mirels and Garret (1971), other instruments to describe work ethic were developed such as Goldstein and Eichorn's Protestant Ethic Scale (1961) and Blood's Pro-Protestant Ethic Scale (1969). In seeking to describe work ethic with a more secular perspective, the Survey of Work Values was developed by Wollack, Goodale, Wijting, and Smith (1971). The measure is considered multidimensional and secular in analyzing work ethic; however, the interpretation of the construct was too broad.

More recently, Hills and Petty (1995) developed the Occupational Work Ethic Inventory (OWEI), which contains 50 items. The instrument seeks to examine work ethic based on the following aspects: interpersonal skills, initiative, and being dependable. The goal of the OWEI is to provide a concise yet accurate measure of work ethic as a construct. The OWEI contains fifty words that would be rated by the respondents through a Likert scale. Interpersonal skill in the OWEI refers to the working relationship of the person with other individuals in the organization. Initiative refers to the aspect which allows the individual to rise through the organization. Being dependable refers to the achievement of expectation with respect to performing one's tasks in the organization. The OWEI was utilized in the study of Hills and Fouts (2005) and Joseph (2010).

To examine work ethic more comprehensively, Miller, Woerh, and Hudspeth (2002) developed the Multidimensional Work Ethic Profile. The questionnaire contains 65 items, which depicts seven facets of work ethic. As defined by the proponents, work ethic is the "commitment to the value of the importance of hard work among potential employees" (Miller, Woehr, \& Hudspeth, 2002, p. 2). It is argued that generational cohort has the possibility to influence work ethic, which is similarly claimed by Joseph (2010). The MWEP contains seven dimensions: hard work, self-reliance, centrality of work, morality/ethics, delay of gratification, wasted time, and leisure. Table 1 shows the definition of each dimension of the Multidimensional Work Ethic Profile (MWEP).

Table 1: MWEP dimensions and definitions from Meriac, Woehr, Gorman, and Thomas (2013)

\begin{tabular}{ll}
\hline Dimension & Definition \\
\hline Centrality of Work & Belief in work for work's sake and the importance of work \\
Self-Reliance & Striving for independence in one's daily work \\
Hard Work & Belief in the virtues of hard work \\
Leisure & Proleisure attitudes and beliefs in the importance of non-work activities \\
Morality/Ethics & Believing in a just and moral existence \\
Delay of Gratification & Oriented toward the future; the postponement of rewards \\
Wasted Time & Attitudes and beliefs reflecting active and productive use of time \\
\hline
\end{tabular}

The proponents of the Multidimensional Work Ethic Profile (MWEP) developed a psychometrically sound instrument in measuring work ethic. This is a significant contribution in this area of study. Other instruments, as mentioned earlier, lacked certain areas or factors. Further, the proponents maintain that they:

Sought to conceptually and empirically identify the structure of work ethic belief, and to develop a current, practical, and psychometrically sound measure of work ethic. Our intent was to develop and evaluate a measure that was conceptually grounded on Weber's original ideas yet current and applicable across religious orientation. (Miller, Woehr, \& Hudspeth, 2002, p. 32) 
Hence, the Multidimensional Work Ethic Profile (MWEP) is, perhaps, one of the most suitable instruments in studying work ethic of individuals in various organizations.

Using the Multidimensional Work Ethic Profile developed by Miller, Woerh, and Hudspeth (2002), Ness, Mellinsky, Buff, and Seifert (2010) compared the work ethic of graduating college university students and those who are in the workforce. Specifically, the dimensions of the Multidimensional Work Ethic Profile were compared with those who are about to begin their professional careers to those who are already working. Results show that graduating college students and working professionals have reported similar work ethic levels. Further, it is reported that students have a stronger leisure ethic and propensity for hard work as compared to professionals. On the other hand, professionals have a stronger disfavor for wasting time and placed greater importance in the centrality of work in their lives.

The Multidimensional Work Ethic Profile is criticized for its length, which discourages some respondents to complete the questionnaire. In order to reduce respondent fatigue and other related concerns, Meriac, Woehr, Gorman, and Thomas (2013) truncated the original MWEP and developed the Multidimensional Work Ethic Profile - Short Form (MWEP-SF). From the original 65 items, the proponents of the more recent work ethic measure only contains 28 items but still targets the original seven domains of work ethic. It is argued that the Multidimensional Work Ethic Scale Short Form (MWEP-SF) strongly correlates with the full MWEP and maintains an equivalent relationship. As argued, the "short form is a more efficient, yet psychometrically-sound measure of work ethic" (Meriac, Woehr, Gorman, \& Thomas, 2013, p. 162).

What is the importance of examining work ethic? Hill and Fouts (2005) argue that a favorable work ethic is highly desired by prospective employers since it leads to increased productivity. Hills and Fouts (2005) further illumine that work ethic also varies with the generation that an individual belongs to. In their study in the US, Baby Boomers are perceived to posses a stronger work ethic than the succeeding generation. On the other hand, Generation X employees are inclined to be less loyal and change jobs frequently. Conversely, individuals who are employed full time have lower work ethic scores as compare to individuals who are employed for less than three months. Ultimately, individuals who have fulfilling jobs scored higher as compared to those who encountered work-related disappointments.

In relation to the concept of work, millennials have been perceived with undesirable work behaviors. Hobart and Sendek (2014) enumerate common description of millennials in relation to work. First they are deemed lazy and expect a reward just by showing up at work. They are also described as self-centered and narcissistic, which explain the "me" generation label. Lastly, they are also depicted as disloyal, pampered, entitled, and lack respect. Jerome, Scales, Whithem, and Quain (2014) reveal similar points. They note that millennials are pampered and coddled. In the workforce, millennials have the belief that they can rise through the ranks quickly. If millennials are not rewarded accordingly, they become dissatisfied and unmotivated. This cavalier attitude also invokes a deficit in their coping skills at work when something goes wrong.

On a positive note, millennials are also deemed as individuals who are achievement oriented, sociable, optimistic, collaborative, and open-minded. It is revealed that millennials' belief in their ability surpasses those from the preceding generations. This can be possibly attributed to their upbringing. The parents of millennials raised their children as active participants in running the household. Hence they tend to be respectful to authority figures but necessarily awed by it. This value discrepancy would sometimes create friction in the workplace and, to some extent, be interpreted as a lack of respect.

Exploring the millennial generation further, Alexander and Sysko (2013) through an extensive literature review and focus group discussion, examined the mindset of entitlement. They opine that the Baby Boomer generation and Generation X, who are presently part of upper and middle management in organizations, are confronted by the onslaught of conflicting attitudes and behaviors of millennials who have entered the workforce. It is said the millennials bring in positive traits in the labor force, some of which are team orientation, work-life balance, loyalty to relationships, commitment to idealistic vision and values, willingness to provide hard word in exchange for virtually immediate reward. There are also some negative traits that were revealed; this includes narcissism, cavalier work attitude, and hedonism as similarly claimed by Hobart and 
Sendek (2014).

Hershatter and Epstein (2010) note that millennials consider technology to be their "sixth sense," as their lives are greatly intertwined with information and communication devices. With their great inclination toward the use of technology, they are considered as "digital natives." Those who lived prior to the development of the Internet are called "digital immigrants." Hershater and Epstein (2010) also provide a dichotomy similar to what Barnes (2009) claimed. For Hershater and Epstein (2010), the millennial generation in the context of work, is either the "Greatest Generation" or "Generation Whine." Considering the former, they are branded as such because they are overprotected and extremely indulged. Some managers complain that millennial employees are unable to do the most mundane task without hand holding, hence "Generation Whine." Alternatively, millennials are called the "Greatest Generation" because they have the inclination toward creating a better future in the midst of economic, environmental, and geo-political issues.

Research on generations and millennials have been steadily rising globally. However, in the Philippine context, there is dearth of scholarship in the said area. Studies have depicted millennials with certain beliefs and values that are different from the previous generations. Further, millennials are polarized into extremes in terms of how they behave at work. Therefore, this preliminary inquiry seeks to describe the work ethic of Filipino millennials particularly in the context of the university and how it is inflected by gender and academic specialization. Further, this present inquiry determined how academic achievement, number of study hours, and workload interacts with the different dimensions of work ethic. Students may not officially have jobs but attending the university requires them to engage in structured and work-like activities, which takes the form completing assignment and attending classes (Hu \& Shaufeli, 2009).

\section{Materials and Methods}

This inquiry utilized the Multidimensional Work Ethic Profile - Short Form. There are seven aspects of work ethic as illumined by Meriac, Woehr, Gorman, and Thomas (2013):

(a) centrality of work, a belief that work is important in its own right, (b) self-reliance, representing a drive toward independence in task accomplishment, (c) hard work, the belief that an increased level of effort is the key to effective task accomplishment, (d) leisure, a value on down-time/nonwork activities, (e) morality/ethics, a proclivity to engage in just/moral behavior, (f) delay of gratification, the capacity to postpone rewards until a later date, and $(g)$ wasted time, a value regarding the productive use of time. (p. 155)

Each question of the 28-item MWEP-SF was answered through a Likert scale ranging from 1 (strongly agree) to 5 (strongly disagree).

It should be noted that the present inquiry has some limitations. The source of the data gathered for this this study was obtained from one private university in Metro Manila, Philippines. Hence, the results may not be fully representative of Filipino millennials in all universities. This project, in essence, provides a preliminary glimpse of millennial work ethic as situated in higher education in the Philippines. The participants of this inquiry are limited to students who are enrolled in engineering and information technology programs. Thus, the results are limited in the sense that other academic specializations were not included.

Table 2: Frequency Profile of Respondents by Gender and Academic Specialization

\begin{tabular}{lc}
\hline Gender & Frequency \\
\hline Male & 183 \\
Female & 65 \\
\hline Academic Specialization & Frequency \\
\hline Information Technology & 160 \\
Engineering & 88 \\
\hline
\end{tabular}

Table 2 shows the summary of the participants of this present inquiry as categorized by academic specialization and gender. The respondents are primarily college students enrolled in private university in Metro Manila, Philippines. Considering purposive sampling, there were 248 
respondents who participated in this inquiry, all of which are born from 1995 onwards. Microsoft SPSS was utilized to analyze the data. To determine the difference in work ethic profile in terms of gender and academic specialization, Mann-Whitney $U$ test was conducted. The Spearman rank order correlation coefficient was utilized to determine the interaction among academic achievement, study hours, workload, and the different dimensions of work ethic. Workload is operationalized through the number of units enrolled and academic achievement was operationalized through the grade point average (GPA) of the respondents.

\section{Results and Discussion}

Table 3: Descriptive Statistics of GPA, Units Enrolled, Study Hours, and MWEP-SF Dimensions

\begin{tabular}{lccccc}
\hline & $\mathrm{n}$ & Minimum & Maximum & Mean & Std. Deviation \\
\hline GPA & 248 & 1.0 & 3.50 & 2.24 & 0.60 \\
Units Enrolled & 248 & 2 & 24 & 17.70 & 3.30 \\
Study Hours & 248 & 1 & 72.00 & 10.56 & 10.68 \\
Wasted Time & 248 & 2.25 & 5.00 & 3.97 & 0.57 \\
Centrality of Work & 248 & 1.50 & 5.00 & 4.04 & 0.57 \\
Morality/Ethics & 248 & 3.00 & 5.00 & 4.36 & 0.51 \\
Leisure & 248 & 1.00 & 5.00 & 3.36 & 0.78 \\
Delay of Gratification & 248 & 2.00 & 5.00 & 4.00 & 0.63 \\
Hard Work & 248 & 2.75 & 5.00 & 4.32 & 0.62 \\
Self-Reliance & 248 & 1.50 & 5.00 & 4.73 & 0.67 \\
\hline
\end{tabular}

Table 3 shows the summary of the variables examined in this study. Among the seven dimensions of work ethic, self-reliance is the highest, which is indicative that the respondents show great independence in accomplishing tasks. Further, the dimensions of wasted time, centrality of work, morality ethics, delay of gratification, and hard work are relatively high as well. This goes to show that the respondents value their productive use of time, work or academic responsibilities, engaging in appropriate or acceptable behavior, deferment of immediate rewards, and exerting great effort for better accomplishment of their work. Leisure appears to be lowest dimension, which reveals that the respondents do not greatly value non-work activities or leisurely pursuits.

There is a notion that millennials seems to prefer group and collaborative work and activities ( $\mathrm{Ng}$, Schweitzer, \& Lyons, 2010). However, the results of the present inquiry reveal that respondent, who are Filipino millennials, do not necessarily favor collaboration as shown in great self-reliance. Alexander and Sysko (2013) note that millennials are willing to work the career ladder for monetary goals and recognition for achievements is expected. The respondents somewhat share the same idea, as shown in high mean for the dimension of hard work. However, a high mean for the delay of gratification also reveal that Filipino millennials do not immediately expect rewards for their achievements.

Table 4: Mann-Whitney U Comparison of the MWEP-SF Subscales by Gender

\begin{tabular}{lccccc}
\hline Work Ethic Dimension & Gender & $\mathrm{n}$ & Mean Ranks & $U$ & $\mathrm{p}$ \\
\hline \multirow{2}{*}{ Wasted Time } & Male & 183 & 119.46 & 5025.00 & 0.061 \\
& Female & 65 & 138.69 & & \\
Centrality of Work & Male & 183 & 116.02 & 4395.00 & 0.002 \\
Morality/Ethics & Female & 65 & 148.38 & & \\
\multirow{2}{*}{ Meisure } & Male & 183 & 120.42 & 5200.00 & 0.127 \\
& Female & 65 & 136.00 & & \\
Delay of Gratification & Male & 183 & 136.06 & 4198.00 & 0.000 \\
& Female & 65 & 97.58 & & \\
Hard Work & Male & 183 & 118.81 & 4911.00 & 0.036 \\
& Female & 65 & 140.45 & & \\
Self-Reliance & Male & 183 & 111.79 & 3621.50 & 0.000 \\
& Female & 65 & 160.28 & & \\
& Male & 183 & 115.01 & 4210.50 & 0.000 \\
\hline
\end{tabular}


Table 4 shows the results of the Mann-Whitney $U$ test of the seven dimensions of work ethic in terms of gender. Results reveal that female respondents significantly have higher mean ranks on centrality of work, delay of gratification, hard work, and self-reliance. Hence, female respondents put greater value on their respective work, postponing rewards, and increased effort in accomplishing tasks, and work independence. On the other hand, male respondents significantly have higher mean rank on leisure. This goes to show that male respondents value non-work activities more than female respondents. In terms of wasted time and morality/ethics, there are no significant differences. Female respondents have higher significant mean ranks in four dimensions of the MWEP-SF as compared to male respondents, which possibly reveals that female millennials have better work ethic than male millennials.

Table 5: Mann-Whitney U Comparison of the MWEP-SF Subscales by Academic Specialization

\begin{tabular}{llcccc}
\hline Work Ethic Dimension & Academic Specialization & $\mathrm{n}$ & Mean Ranks & $U$ & $\mathrm{p}$ \\
\hline \multirow{2}{*}{ Wasted Time } & Information Technology & 160 & 121.72 & \multirow{2}{*}{6595.00} & \multirow{2}{*}{0.406} \\
& Engineering & 88 & 129.56 & & \\
Centrality of Work & Information Technology & 160 & 121.30 & 6528.50 & 0.340 \\
\multirow{2}{*}{ Morality/Ethics } & Engineering & 88 & 130.31 & & \\
\multirow{2}{*}{ Leisure } & Information Technology & 160 & 122.00 & 6639.50 & 0.452 \\
\multirow{2}{*}{ Delay of Gratification } & Engineering & 88 & 129.05 & & \\
\multirow{2}{*}{ Hard Work } & Information Technology & 160 & 128.52 & 6396.50 & 0.231 \\
\multirow{2}{*}{ Self-Reliance } & Engineering & 88 & 117.19 & & \multirow{2}{*}{ Information Technology } \\
& Engineering & 88 & 125.63 & 6860.00 & 0.737 \\
& Information Technology & 160 & 125.45 & & \\
& Engineering & 88 & 122.96 & 6904.00 & 0.800 \\
& Information Technology & 160 & 122.03 & 6645.00 & \multirow{2}{*}{0.462} \\
\hline
\end{tabular}

Table 5 shows the results of the Mann-Whitney $U$ test of the seven dimensions of work ethic in terms of academic specialization. Results reveal that there is no significant difference between students who specializes in information technology and engineering.

Table 6: Aggregate Correlation of GPA, Units Enrolled, Study Hours, and the MWEP-SF Subscales

\begin{tabular}{lccccccc}
\hline & $\begin{array}{c}\text { Wasted } \\
\text { Time }\end{array}$ & $\begin{array}{c}\text { Centrality of } \\
\text { Work }\end{array}$ & $\begin{array}{c}\text { Morality/ } \\
\text { Ethics }\end{array}$ & Leisure & $\begin{array}{c}\text { Delay of } \\
\text { Gratification }\end{array}$ & $\begin{array}{c}\text { Hard } \\
\text { Work }\end{array}$ & $\begin{array}{c}\text { Self- } \\
\text { Reliance }\end{array}$ \\
\hline GPA & 0.03 & 0.17 & $.13^{*}$ & -0.02 & 0.05 & 0.06 & -0.03 \\
Units Enrolled & -0.07 & -0.09 & -0.07 & -0.07 & $-.15^{*}$ & -0.037 & $-.13^{*}$ \\
Study Hours & -0.07 & -0.08 & -0.11 & 0.02 & -0.07 & 0.01 & -0.08 \\
\hline
\end{tabular}

Note: ${ }^{*} p<.05$

Table 6 shows the aggregate correlation among GPA, units enrolled, study hours and the seven dimensions of the MWEP-SF. Based on the analysis, academic achievement as operationalized through GPA is positively correlated with morality/ethics, $r_{s}=.13, p<.05$. On the other hand, workload as operationalized through the number of units enrolled is negatively correlated with delay of gratification, $r_{s}=-.15, p<.05$ and self-reliance, $r_{s}=-.13, p<.05$. Hence, it can be deduced that the rise in academic achievement or GPA also leads to an increased proclivity toward engaging in ethical behavior. When academic workload of the respondents increases, delay of gratification and self-reliance decreases. Higher workload may reduce the respondent's ability to delay rewards for accomplishments and to rely on one's own ability to accomplish tasks. 
Table 7: Correlation of GPA, Units Enrolled, Study Hours, and the MWEP-SF Subscales by Gender

\begin{tabular}{llccccccc}
\hline & Gender & $\begin{array}{c}\text { Wasted } \\
\text { Time }\end{array}$ & $\begin{array}{c}\text { Centrality of } \\
\text { Work }\end{array}$ & $\begin{array}{c}\text { Morality/ } \\
\text { Ethics }\end{array}$ & Leisure & $\begin{array}{c}\text { Delay of } \\
\text { Gratification }\end{array}$ & $\begin{array}{c}\text { Hard } \\
\text { Work }\end{array}$ & $\begin{array}{c}\text { Self- } \\
\text { Reliance }\end{array}$ \\
\hline GPA & Male & 0.06 & 0.11 & 0.06 & -0.04 & 0.05 & 0.02 & -0.08 \\
\multirow{4}{*}{ Units Enrolled } & Female & -0.15 & 0.06 & $.26^{*}$ & 0.09 & 0.12 & 0.5 & -0.02 \\
\multirow{2}{*}{ Study Houre } & -0.06 & -0.08 & -0.06 & 0.00 & $-17^{*}$ & 0.00 & -0.10 \\
& Female & -0.10 & -0.13 & -0.14 & $-.26^{*}$ & -0.13 & -0.18 & -0.23 \\
& Male & -0.10 & -0.11 & -0.09 & 0.04 & -0.03 & 0.06 & -0.03 \\
& Female & 0.06 & 0.06 & -0.19 & -0.07 & -0.17 & -0.11 & -0.16 \\
\hline
\end{tabular}

Note: ${ }^{*} p<.05$

Table 7 shows the correlation among GPA, units enrolled, study hours and the seven dimensions of the MWEP-SF as differentiated by gender. Result reveal that for female respondents, GPA is positively correlated with morality/ethics, $r_{s}=.26, p<.05$. However, for female respondents, the analysis shows that the correlation between units enrolled and leisure is negative, $r_{\mathrm{s}}=-.26, p<.05$. Considering male respondents, the correlation between units enrolled and delay of gratification is negative, $r_{s}=.17, p<.05$. Hence, for female millennial university students, it is revealed that greater academic achievement is positively linked to behaving ethically. However, for female respondents, higher workload leads to less regard for non-work or leisurely activities. Male respondents with higher workloads tend to have lesser capacity to postpone rewards for their accomplishments.

Table 8: Correlation of GPA, Units Enrolled, Study Hours, and the MWEP-SF Subscales by Academic Specialization

\begin{tabular}{|c|c|c|c|c|c|c|c|c|}
\hline & $\begin{array}{l}\text { Academic } \\
\text { Specialization }\end{array}$ & $\begin{array}{c}\text { Wasted } \\
\text { Time }\end{array}$ & $\begin{array}{c}\text { Centrality } \\
\text { Work }\end{array}$ & $\begin{array}{c}\text { Morality/ } \\
\text { Ethics }\end{array}$ & Leisure & $\begin{array}{c}\text { Delay of } \\
\text { Gratification }\end{array}$ & $\begin{array}{l}\text { Hard } \\
\text { Work }\end{array}$ & $\begin{array}{c}\text { Self } \\
\text { Reliance } \\
\end{array}$ \\
\hline \multirow[t]{2}{*}{ GPA } & $\begin{array}{l}\text { Information } \\
\text { Technology }\end{array}$ & 0.12 & $.16^{*}$ & 0.09 & 0.04 & 0.12 & 0.09 & 0.040 \\
\hline & Engineering & -0.10 & 0.04 & $.22^{*}$ & -0.14 & -0.06 & 0.01 & -0.13 \\
\hline \multirow[t]{2}{*}{ Units Enrolled } & $\begin{array}{l}\text { Information } \\
\text { Technology }\end{array}$ & -0.04 & -0.12 & $-.16^{*}$ & -0.11 & $-.16^{*}$ & -0.03 & -0.15 \\
\hline & Engineering & -0.15 & -0.03 & 0.10 & -0.01 & -0.17 & -0.07 & -0.11 \\
\hline \multirow[t]{2}{*}{ Study Hours } & $\begin{array}{l}\text { Information } \\
\text { Technology }\end{array}$ & -0.10 & -0.09 & $-.20^{*}$ & 0.13 & -0.08 & -0.03 & 0.00 \\
\hline & Engineering & -0.02 & -0.06 & 0.053 & $.25^{*}$ & -0.07 & -0.01 & -0.19 \\
\hline
\end{tabular}

Note: ${ }^{*} p<.05$

Table 8 shows the correlation among GPA, units enrolled, study hours and the seven dimensions of the MWEP-SF as differentiated by academic specialization. GPA, for respondents specializing on information technology, is positively correlated with centrality of work, $r_{s}=.16, p<.05$. Units enrolled for information technology students is negatively correlated with morality/ethics, $r_{s}=-.16, p$ $<.05$ and delay of gratification, $r_{s}=-.16, p<.05$. Study hour is also negatively correlated to morality/ethics for information technology students, $r_{s}=.20, p<.05$. Considering engineering students, GPA is positively correlated with centrality of work, $r_{s}=.16, p<.05$; and study hours is positively correlated with leisure, $r_{s}=.25, p<.05$.

The results reveal that academic achievement, workload, and study hours interact with the various facets of work ethic with respect to academic specialization. For respondents specializing in information technology, higher academic achievement leads to greater centrality of work, that is, they value the work that they do. Conversely, greater workload and increased study hours possibly leads to a decreased tendency for the respondents to behave ethically and to delay rewards for accomplishments. On the other hand, students specializing in engineering, greater academic achievement more likely increases one's predisposition toward behaving ethically. Furthermore, engineering students who render more study hours also have greater esteem for non-work or leisurely activities. 


\section{Conclusion}

This study explored the work ethic profile of Filipino millennial university students through the Multidimensional Work Ethic Profile - Short Form developed by Meriac, Woehr, Gorman, and Thomas (2013). In addition, the difference between the work ethic profile in terms of gender and academic specialization was examined. The respondents, for the most part, show great selfreliance. Overall, they have high means on the dimensions of centrality of work, wasted time, morality/ethics, delays of gratification, and hard work. However, the dimension of leisure has the lowest mean as compared to the other dimensions of work ethic. The findings suggest that millennial university students exhibit great independent in fulfilling their respective work. This might possibly go against notions that all millennials prefer collaborative or group tasks. On the aspect of leisure, Filipino millennial university students, perhaps, do not give great importance on non-work or leisurely diversions.

Aside form analyzing the work ethic profile of the respondents; differences were also determined in terms of gender and academic specialization using the Mann-Whitney $U$ test. Male respondents have significantly higher mean ranks on the dimension of leisure. On the other hand, female respondents have significantly higher mean ranks on the dimensions of centrality of work, delay of gratification, hard work, and self-reliance. Thus, it can be deduced that Filipino female millennial university students more likely have better work ethic than male millennial university students. Considering the difference in academic specialization, the findings reveal that there are no significant differences between information technology and engineering students.

Academic achievement, workload, and study hours also influence certain facets of the work ethic profile of the respondents as examined through the Spearman rank order correlation. Academic achievement was operationalized through the grade point average of the respondents while workload was operationalized through the number of units enrolled. Academic achievement is positively correlated with morality/ethics. In addition, workload is negatively correlated with delay of gratification and self-reliance. This suggests that millennial university students who have higher academic achievement tend to behave more ethically. Considering workload, it can be construed that higher workload for millennial university students leads to increased tendency for more immediate rewards and higher chances for seeking collaboration for accomplishing tasks.

Further analysis shows that the correlations among academic achievement, workload, study hours and the different dimensions of work ethic differ. Taking gender into account, academic achievement for female millennial university students is positively correlated with morality/ethics while workload is negatively correlated with leisure. For male millennial university students, workload is negatively correlated with delay of gratification. This reveals that higher academic achievement for female respondents possibly leads to more ethical behavior. Higher workload, for female millennial university students, possibly leads to lower priority of non-work or leisurely activities. Considering male respondents, higher workload leads to more immediate expectation of rewards for accomplishment of tasks.

The interaction between academic achievement, workload, study hours, and the different dimensions of work ethic have significant differences in terms of academic specialization. For respondents specializing in information technology, academic achievement is positively correlated with centrality of work. However, workload for information technology students is negatively correlated with morality/ethics and delay of gratification. Likewise, study hours for information technology students, is negatively correlated with morality/ethics. Therefore, higher academic achievement for information technology student leads to a higher belief on the importance of their work. On the other hand, higher workload may lead to less morally appropriate behavior and more immediate rewards for accomplishment of tasks. Focusing on engineering students, academic achievement is positively correlated with morality/ethics and study hours is positively correlated with leisure. Hence, higher academic achievement for engineering students possibly leads to higher instances of behaving ethically. In similar vein, higher study hours more likely leads to greater consideration of non-work and leisurely pursuits for engineering students.

Overall, this inquiry elaborates on the work ethic profile of millennial university students. Aside from generational differences in describing a particular cohort, this study also considered the 
cultural aspect in describing a specific generation. Myers and Sadaghiani (2010) note that millennials in general are perceived to be "self-centered [and] unmotivated" (p. 225). In the context of Filipino millennials, such may not necessarily be always true. The present inquiry shows that Filipino millennial university students show great self-reliance, perhaps, other people might inaccurately interpret this as being self-centered. Likewise, being unmotivated is contingent to the milieu where millennials are situated. As can be seen in this inquiry, work ethic interacts with different factors such as academic achievement, workload, and study hours; hence the claim that millennials are unmotivated should be further examined and put into scrutiny.

\section{Recommendations}

The purpose of this inquiry was to examine the work ethic profile of millennial university students in a private university in Manila. The results of the study show that there are significant differences between the work ethic profile of male and female respondents. Furthermore, academic achievement, workload, and study hours interact with the different facets of work ethic. Therefore, the following recommendations are made to enrich this area of study:

- The work ethic of currently employed millennials should be explored and compared with the work ethic of millennial university students.

- Examination of work ethic among the different generations may be conducted to have a holistic view of Filipino work ethic.

- Other instruments in describing work ethic may be utilized to obtain a more detailed description of the work ethic of Filipino millennials.

- $\quad$ Further studies may utilize a more focused approach by using interview or focus group discussion to elucidate on millennial work ethic in the Philippines.

The following items are recommendation for the improvement of managing millennials in the universities.

- Given that millennial university students have great self-reliance, decision-makers ought to consider how millennials can utilize such to improve their interpersonal relationship with other individuals.

- Academic achievement interacts positively with behaving ethically. Hence, those with lower academic achievement should be given greater attention in order to enhance their academic standing and, consequently, develop a more positive attitude.

\section{References}

Alexander, C. S., \& Sysko, J. M. (2013). I'm Gen Y, I love feeling entitled, and it shows. Academy of Educational Leadership, 17(4), 127-131.

Barnes, G. (2009). Guess who's coming to work: Generation Y. Are you ready for them? Public Library Quarterly, 28(1), 58-63.

Blood, M. R. (1969). Work values and job satisfaction. Journal of Applied Psychology, 53(6), 456-459.

Buchholz, R. A. (1977). The belief structure of managers relative to work concepts measured by a factor analytic model. Personnel Psychology, 30(4), 567-587.

Cates, S. V. (2014). The young and the restless: Why don't millenials join unions? International Journal of Business and Public Administration, 11(2), 107-119.

Chasovschi, C. (2016). Perspectives on work ethic: An intercultural approach. The USV Annals of Economics and Public Administration. 16, 93-98.

Delcampo, R. G., Haggerty, L. A., Haney, M. J., \& Knippel, L. A. (2001). Managing the Multi-Generational Workforce. Surrey: Gower Publishing Limited.

Goldstein, B., \& Eichhorn, R. (1961). The changing Protestant ethic: Rural patterns in health, work and leisure. American Sociological Review, 26, 557-565.

Hershatter, A., \& Epstein, M. (2010). Millennials and the world of work: An organization and management perspective. Journal of Business and Psychology, 25(2), 211-223.

Hill, R., \& Fouts, S. (2005). Work ethic and employment status: A study of jobseekers. Journal of Industrial Teacher Education, 42(3), 48-64.

Hill, R., \& Petty, C. (1995). A new look at selected employability skills: A factor analysis of the occupational work. Journal of Vocational Educational Research, 20(4), 59-73. 
Hobart, B., \& Sendek, H. (2014). Gen Y Now: Millennials and the Evolution of Leadership. California: Wiley.

Hu, Q., \& Schaufeli, W. B. (2009). The factorial validity of the Maslach Burnout Inventory - Student Survey in China. Psychological Reports, 105(2), 394-408.

Jerome, A., Scales, M., Whithem, C., \& Quain, B. (2014). Millenials in the workforce: Gen Y workplace strategies for the next century. e-Journal of Social \& Behavioral Research in Business, 5(1), 1-12.

Joseph, J. A. (2010). How generation, gender, and personality affect work ethic: Guiding managers in leading a diverse workforce (Doctoral dissertation). Retrieved from Proquest Dissertation and Theses Database. (Accession No. 922420812)

Meriac, J. P., Woehr, D. J., \& Banister, C. (2010). Generational differences in work ethic: An examination of measurement equivalence across three cohorts. Journal of Business and Psychology, 25(2), 315-324.

Meriac, J. P., Woehr, D. J., Gorman, C. A., \& Thomas, A. L. (2013). Development and validation of a short form for the multidimensional work ethic profile. Journal of Vocational Behavior, 82(3), 155-164.

Miller, M. J., Woehr, D. J., \& Hudspeth, N. (2001). The meaning and measurement of work ethic: Construction and initial validation of a multidimensional inventory. Journal of Vocational Behavior, 17(5), 1-39.

Mirels, H. L., \& Garrett, J. B. (1971). The Protestant ethic as a personality variable. Journal of Consulting and Clinical Psychology, 36(1), 40-44.

Myers, K. K., \& Sadaghiani, K. (2010). Millennials in the workplace: A communication perspective on millennials' organizational relationship and performance. Journal of Business Psychology, 25(2), 225-238.

Ness, R. K., Melinsky, K., Buff, C., \& Seifert, C. (2010). Work ethic: Do new employees mean new work values? Journal of Managerial Issues, 22(1), 10-34.

Ng, E. S., Schweitzer, L., \& Lyon, S. T. (2010). New generation, great expectations: A field study of the millennial generation. Journal of Business Psychology, 25, 281-292.

Sullivan, P., \& Heitmeyer, J. (2008). Looking at Gen Y shopping preferences and intentions: Exploring the role of experience and apparel involvement. International Journal of Consumer Studies, 32(3), 285-295.

Wollack, S., Goodale, J. G., Wijting, J. P., \& Smith, P. C. (1971). Development of the Survey of Work Values. Journal of Applied Psychology, 55(4), 331-338.

Weber, M. (1905). The Protestant Ethic and the Spirit of Capitalism. London: Routledge 